\title{
TINGKAT LITERASI KEUANGAN PADA MAHASISWA S-1 FAKULTAS EKONOMI
}

\author{
Farah Margaretha ${ }^{1^{*}}$, Reza Arief Pambudhi ${ }^{1}$ \\ ${ }^{1}$ Fakultas Ekonomi Universitas Trisakti \\ Jalan Kyai Tapa, Grogol, Jakarta 11440, Indonesia \\ *Penulis Korespondensi; E-mail: farahmargaretha@yahoo.com
}

\begin{abstract}
Abstrak
Penelitian ini bertujuan untuk meneliti bagaimana tingkat literasi keuangan mahasiswa S1 dan faktor yang mempengaruhinya. Penelitian ini menggunakan kuesioner yang disebarkan sebanyak 625 kuesioner dan hanya 584 kuesioner yang dapat digunakan. Metode analisis data adalah statistik deskriptif dan uji ANOVA. Tingkat literasi keuangan adalah 48,91\% berada dalam kategori rendah. Hasil pengujian menunjukkan terdapat pengaruh antara jenis kelamin, usia, IPK, dan pendapatan orang tua. Hasil tersebut menunjukkan bahwa mahasiswa harus meningkatkan pemahaman mereka tentang personal finance khususnya dalam area investasi. Selain itu universitas dapat memberi pendidikan tentang personal finance kepada mahasiswa. Saran untuk penelitian selanjutnya adalah meneliti seluruh mahasiswa Universitas Trisakti, menggunakan metode online, menambah jumlah pertanyaan dan menambah variabel seperti pendapatan mahasiswa, kepemilikan tabungan, hutang dan pengalaman kerja mahasiswa.
\end{abstract}

Kata kunci: Literasi keuangan, personal finance, jenis kelamin, usia, IPK

\begin{abstract}
The purpose of this research was to examine the level of financial literacy and the factors that influence undergraduate students of Faculty of Economics. This study distributed 625 questionnaires and only 584 usable questionnaires. Data analysis methods used by this research were descriptive statistics and ANOVA. The level of financial literacy was $48.91 \%$ were in the low category. The test results revealed that there was influence of gender, age, GPA, and parents income. The results showed that students should improve their understanding of personal finance, especially in the area of investment, in addition to the university to provide education about personal finance to students. Suggestions for further research was examined throughout the Trisakti University students, using online methods, increasing the number of questions and adding variables such as student income, savings and debt holdings and work experience students.
\end{abstract}

Keywords: Financial literacy, personal finance, gender, age, GPA

\section{Pendahuluan}

Kecerdasan finansial merupakan salah satu aspek penting dalam kehidupan saat ini. Kecerdasan finansial adalah kecerdasan dalam mengelola aset pribadi (Widayati, 2012). Individu harus memiliki suatu pengetahuan dan keterampilan untuk mengelola sumber keuangan pribadinya secara efektif demi kesejahteraannya. Selain menetapkan keputusan keuangan jangka pendek seperti tabungan dan pinjaman, individu juga harus memikirkan keputusan keuangan jangka panjang seperti perencanaan pensiun dan perencanaan pendidikan untuk anak-anaknya. Literasi keuangan telah berkembang dalam beberapa tahun terakhir dan mendapatkan perhatian yang lebih, khususnya pada negara-negara maju. Istilah literasi keuangan adalah kemampuan seorang individu untuk mengambil keputusan dalam hal pengaturan ke- uangan pribadinya. Remund (2010) menjelaskan lima domain dari literasi keuangan yakni 1) Pengetahuan tentang konsep keuangan 2) Kemampuan untuk berkomunikasi tentang konsep keuangan 3) Kemampuan untuk mengelola keuangan pribadi 4) Kemampuan dalam membuat keputusan keuangan 5) Keyakinan untuk membuat perencanaan keuangan masa depan.

Literasi keuangan telah berkembang pesat selama beberapa tahun terakhir. Beberapa faktor yang menyebabkan literasi keuangan berkembang antara lain tingkat bunga tabungan yang rendah, meningkatnya tingkat kebangkrutan dan tingkat hutang, dan meningkatnya tanggung jawab individu untuk membuat keputusan yang akan mempengaruhi perekonomian mereka di masa depan (Servon \& Kaestner, 2008).

Literasi keuangan sangat berkaitan dengan kesejahteraan seorang individu. Pengetahuan keuangan dan keterampilan dalam mengelola keuangan pribadi 
sangat penting dalam kehidupan sehari-hari, Krishna, Rofaida, dan Sari (2010) menjelaskan bahwa literasi keuangan membantu individu agar terhindar dari masalah keuangan. Kesulitan keuangan bukan hanya fungsi dari pendapatan semata (rendahnya pendapatan). Kesulitan keuangan juga dapat muncul jika terjadi kesalahan dalam pengelolaan keuangan (missmanagement) seperti kesalahan penggunaan kredit, dan tidak adanya perencanaan keuangan. Keterbatasan finansial dapat menyebabkan stress, dan rendahnya kepercayaan diri. Adanya pengetahuan keuangan dan literasi keuangan akan membantu individu dalam mengatur perencanaan keuangan pribadi, sehingga individu tersebut bisa memaksimalkan nilai waktu uang dan keuntungan yang diperoleh oleh individu akan semakin besar dan akan meningkatkan taraf kehidupannya. Bhushan and Medury (2013) menjelaskan literasi keuangan sangat penting karena beberapa alasan. Konsumen yang memiliki literasi keuangan bisa melalui masa-masa keuangan yang sulit karena faktanya bahwa mereka mungkin memiliki akumulasi tabungan, membeli asuransi dan diversifikasi investasi mereka. Literasi keuangan juga secara langsung berkorelasi dengan perilaku keuangan yang positif seperti pembayaran tagihan tepat waktu, angsuran pinjaman, tabungan sebelum habis dan menggunakan kartu kredit secara bijaksana.

Bhushan and Medury (2013) menjelaskan literasi keuangan telah menjadi semakin kompleks selama beberapa tahun terakhir dengan pengenalan banyak produk keuangan baru. Dalam rangka untuk memahami risiko dan keuntungan yang terkait dengan produk keuangan, tingkat minimum literasi keuangan sudah menjadi suatu keharusan. Individu yang memiliki literasi keuangan dapat membuat penggunaan yang efektif dari produk dan jasa keuangan sehingga individu tidak akan mudah ditipu oleh orang-orang yang menjual produk-produk keuangan yang tidak sesuai dengan individu tersebut. Literasi keuangan membantu untuk meningkatkan kualitas pelayanan keuangan dan memberikan kontribusi terhadap pertumbuhan ekonomi dan pembangunan suatu negara. Semakin meningkatnya kompleksitas ekonomi, kebutuhan individu dan produk keuangan, individu harus memiliki literasi keuangan untuk mengatur keuangan pribadinya.

Pengetahuan tentang keuangan sangat penting bagi seorang individu, agar mereka tidak salah dalam membuat keputusan keuangan mereka. Pengetahuan tentang keuangan yang kurang, mengakibatkan kerugian bagi individu, baik akibat dari inflasi, penurunan kondisi perekonomian baik dalam negeri maupun luar negeri, atau berkembangnya sistem perekonomian. Nidar dan Bestari (2012) menjelaskan bahwa perekonomian nasional tidak akan berpengaruh pada krisis keuangan global jika masyarakat memahami sistem keuangan. Kesalahpahaman menyebabkan banyak orang mengalami kerugian keuangan, sebagai akibat dari pengeluaran yang boros dan konsumsi, tidak bijaksana dalam penggunaan kartu kredit, dan menghitung perbedaan antara kredit konsumen dan pinjaman bank. Selain itu, kurangnya pengetahuan tentang keuangan menyebabkan seseorang sulit untuk melakukan investasi atau mengakses ke pasar keuangan.

Bagi sebagian besar mahasiswa, masa kuliah adalah saat pertama mereka mengelola keuangannya sendiri tanpa adanya pengawasan dari orang tua (Sabri et al. 2008). Mahasiswa akan menghadapi permasalahan yang mungkin baru dan menghadapi lingkungan yang baru tanpa adanya pengawasan dan dukungan dari orang tua. Mahasiswa harus bisa secara mandiri mengatur keuangannya dengan baik dan juga harus bisa bertanggung jawab atas keputusan yang telah mereka buat. Permasalahan-permasalahan keuangan yang sering timbul pada mahasiswa adalah mereka belum memiliki pendapatan, sebagian dari mahasiswa masih bergantung kepada orang tua. Selain itu, sikap boros dari mahasiswa merupakan permasalahan yang sering dihadapi.

Banyak penelitian yang dilakukan pada mahasiswa dan hasilnya menunjukan bahwa pengetahuan tentang literasi keuangan masih sangat rendah. Mahasiswa sebagai generasi muda sejak dini harus memiliki pengetahuan di bidang personal finance karena pengetahuan tersebut akan membantu mahasiswa dalam mengatur keuangannya di masa depan. Chen and Volpe (1998) menjelaskan bahwa mahasiswa yang memiliki pengetahuan yang rendah akan membuat keputusan salah dalam keuangan mereka. Hal ini menunjukkan bahwa pengetahuan di bidang personal finance akan mempengaruhi mahasiswa dalam mengambil keputusan keuangan yang baik.

Widayati (2012) menjelaskan pembelajaran di perguruan tinggi sangat berperan penting dalam proses pembentukan literasi finansial mahasiswa. Mahasiswa tinggal di lingkungan ekonomi yang beragam dan kompleks sehingga peningkatan kebutuhan pendidikan keuangan sangat diperlukan. Pembelajaran yang efektif dan efisien akan membantu mahasiswa memiliki kemampuan memahami, menilai, dan bertindak dalam kepentingan keuangan mereka. Adanya pengetahuan yang baik sejak dini diharapkan mahasiswa dapat memiliki kehidupan yang sejahtera di masa yang akan mendatang.

Penelitian ini bertujuan 1) Menganalisis secara deskriptif tingkat literasi keuangan pada mahasiswa 
Strata I Fakultas Ekonomi 2) Menganalisis secara deskriptif tingkat literasi keuangan pada mahasiswa Strata I Fakultas Ekonomi berdasarkan faktor demografik 3) Menganalisis apakah terdapat pengaruh antara jenis kelamin, usia, tahun masuk mahasiswa (angkatan), IPK, tempat tinggal mahasiswa, pendidikan orang tua dan pendapatan orang tua terhadap literasi keuangan mahasiswa,

Keuangan merupakan aspek penting yang melekat dalam kehidupan masyarakat luas. Pengetahuan keuangan yang dimiliki dapat membantu individu dalam menentukan keputusan-keputusan dalam menentukan produk-produk finansial yang dapat mengoptimalkan keputusan keuangannya. Penegertian literasi keuangan, dalam Vitt et al. (2000) adalah kemampuan untuk membaca, menganalisis, mengelola dan berkomunikasi tentang kondisi keuangan pribadi yang akan mempengaruhi kesejahteraan material. Pengertian literasi keuangan, menurut Bhushan and Medury (2013) adalah kemampuan untuk membuat penilaian informasi dan mengambil keputusan yang efektif tentang penggunaan dan pengelolaan uang. Pengertian literasi keuangan, dalam ANZ Bank (2011) adalah kemampuan untuk membuat penilaian informasi dan membuat keputusan yang efektif mengenai penggunaan dan pengelolaan uang. Literasi keuangan adalah kombinasi dari kemampuan individu, pengetahuan, sikap dan akhirnya perilaku individu yang berhubungan dengan uang. Berdasarkan definisi-definisi tersebut dapat disimpulkan bahwa literasi keuangan adalah pengetahuan individu tentang keuangan dan kemampuan individu untuk membuat keputusan keuangan yang efektif.

Pengetahuan tentang keuangan yang kurang akan mengakibatkan kerugian bagi individu, baik akibat dari inflasi, penurunan kondisi perekonomian baik dalam negeri maupun luar negeri, atau berkembangnya sistem perekonomian yang menjadikan masyarakat lebih konsumtif atau lebih menjadi boros. Selain itu, kurangnya pengetahuan tentang keuangan menyebabkan seseorang sulit untuk melakukan investasi atau mengakses ke pasar keuangan. Krishna et al. (2010) menjelaskan bahwa literasi keuangan membantu individu agar terhindar dari masalah keuangan. Kesulitan keuangan bukan hanya fungsi dari pendapatan semata (rendahnya pendapatan). Kesulitan keuangan juga dapat muncul jika terjadi kesalahan dalam pengelolaan keuangan (miss-management) seperti kesalahan penggunaan kartu kredit, dan tidak adanya perencanaan keuangan. Keterbatasan finansial dapat menyebabkan stress, dan rendahnya kepercayaan diri.

Chen and Volpe (1998) mengkategorikan literasi keuangan menjadi tiga kelompok, yaitu 1) $<60 \%$ yang berarti individu memiliki pengetahuan tentang keuangan yang rendah 2) 60\%-79\%, yang berarti individu memiliki pengetahuan tentang keuangan yang sedang dan 3) > 80\% yang menunjukkan bahwa individu memiliki pengetahuan keuangan yang tinggi. Pengkategorian ini didasarkan pada presentase jawaban responden yang benar dari sejumlah pertanyaan yang digunakan untuk mengukur literasi keuangan. Tingkat literasi keuangan di Indonesia berada dalam tingkat yang rendah dibandingkan dengan negara lain. Hal tersebut juga terungkap dalam survei yang dilakukan oleh Visa (2012) mengenai Visa International Financial Literacy Barometer yang dilakukan di 28 negara. Survei tersebut menunjukkan bahwa Indonesia berada pada posisi ke27 dengan skor 27,7 berada di bawah negara Vietnam dan di atas negara Pakistan. Adapun di peringkat tiga teratas dari survei tersebut adalah Brazil, Meksiko, dan Australia. Survei dilakukan terhadap 25.500 partisipan di 28 negara sepanjang Pebruari-April 2012.

Otoritas jasa keuangan (OJK) menjelaskan kondisi akses masyarakat Indonesia ke lembaga keuangan formal masih sangat rendah dibandingkan dengan negara-negara di Asia. Berdasarkan data yang diteliti oleh Worldbank (2011), Indonesia menempati posisi ke-6 dari enam negara Asia dengan persentase sebesar 20\% dan berada di bawah negara Filipina.

Chen and Volpe (1998) melakukan penelitian tentang literasi keuangan dengan responden sebanyak 924 mahasiswa dan menemukan bahwa tingkat literasi keuangan berada dalam kategori yang rendah. Hasil penelitian menunjukkan bahwa mahasiswa menjawab 53\% dari pertanyaan dengan benar. Nababan dan Sadalia (2012) melakukan penelitian dengan jumlah responden sebanyak 97 mahasiswa. Sampel yang diambil merupakan mahasiswa S-1 (Strata I) Fakultas Ekonomi yang masih aktif dari angkatan 2008 sampai dengan 2011. Dalam penelitiannya menemukan bahwa tingkat literasi keuangan mahasiswa sebesar 56,61\% yang menunjukkan bahwa tingkat literasi finansial masih berada dalam kategori yang rendah. Nidar dan Bestari (2012) dalam penelitiannya yang dilakukan dengan jumlah responden sebanyak 400 mahasiswa yang masih aktif menemukan bahwa tingkat literasi keuangan berada dalam kategori yang rendah. Dalam penelitiannya, mahasiswa perlu meningkatkan pengetahuan di bidang investasi, hutang dan asuransi. Indikator pertanyaan -pertanyaan dalam penelitian ini adalah basic personal finance, income \& spending, credit \& debt, saving \& investment and insurance. Bhushan and Medury (2013) menjelaskan tingkat literasi keuangan pada individu yang sudah bekerja dan mendapatkan gaji secara keseluruhan adalah 
sebesar 58,30\%. Ibrahim and Alqaydi (2013) melakukan penelitian terhadap masyarakat yang berada di UEA dan menemukan bahwa rata-rata literasi keuangan adalah sebesar $43,33 \%$.

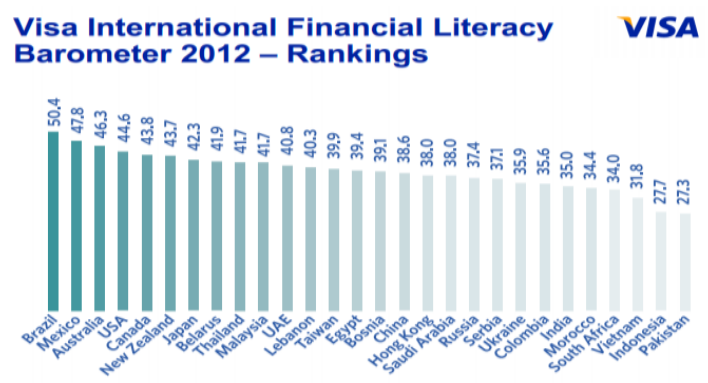

Gambar 1. Survei Tingkat Literasi Keuangan

Sumber: Visa (2012)

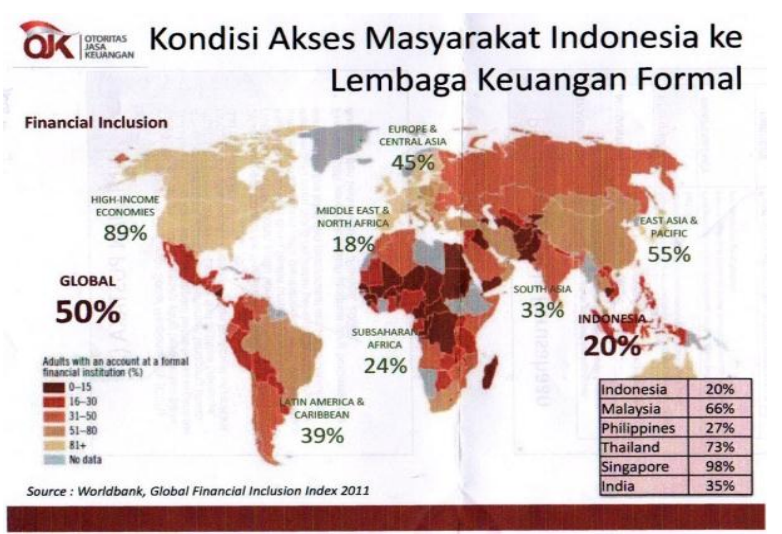

Gambar 2. Kondisi Akses Masyarakat Asia ke Lembaga Keungan Formal

Sumber: Worldbank (2011)

\section{Pengembangan Hipotesis}

Chen and Volpe (1998) dalam penelitiannya menjelaskan bahwa laki-laki lebih memahami financial literacy dibandingkan perempuan. Penelitian tersebut dilakukan dengan mengadakan survei di Universitas dengan sampel sebanyak 924 siswa. Krishna et al. (2010) dalam penelitiannya menemukan bahwa wanita lebih memahami financial literacy dibandingkan dengan laki-laki. Penelitian tersebut dilakukan kepada 100 mahasiswa yang masih aktif dari angkatan 2006 sampai 2008. Bhushan and Medury (2013) melakukan penelitian di India dengan 516 responden, dalam penelitianya menemukan bahwa terdapat perbedaan yang signifikan antara responden laki-laki dan perempuan yang sudah memiliki gaji dalam hal literasi keuangan. Berdasarkan penelitian-penelitian di atas dapat dirumuskan hipotesis yakni $H_{l}$ : Jenis kelamin mempengaruhi literasi keuangan mahasiswa.
Chen and Volpe (1998) menemukan tingkat literasi keuangan yang rendah pada peserta yang berusia 18-22 tahun. Alasan untuk rendahnya tingkat pengetahuan dapat dikaitkan dengan usia muda 18 sampai 22 tahun dari peserta atau di bawah 30 tahun sebagai mayoritas dari mereka berada dalam tahap yang sangat awal siklus dari hidup finansial mereka. Saat tahap siklus ini, mereka memiliki sejumlah masalah keuangan yang berkaitan dengan pengetahuan umum tentang keuangan, tabungan dan pinjaman, dan asuransi. Saat periode ini, sebagian besar pendapatan mereka dibelanjakan konsumsi daripada investasi. Taft, Hosein, and Mehrizi (2013) menemukan terdapat hubungan positif antara usia dengan literasi keuangan dan financial wellbeing. Shaari, Hasan, Mohamed, and Sabri (2013) dalam penelitiannya yang dilakukan pada mahasiswa di Malaysia dengan sampel sebanyak 384, menemukan bahwa terdapat hubungan negatif antara literasi keuangan mahasiswa dengan usia. Ansong and Gyensare (2012) menemukan bahwa usia memiliki hubungan dengan literasi keuangan pada mahasiswa. Berdasarkan penelitian tersebut, maka hipotesisnya adalah $\mathrm{H}_{2}$ : Usia mempengaruhi literasi keuangan mahasiswa.

Chen and Volpe (1998) menemukan bahwa mahasiswa yang lebih senior memiliki tingkat literasi keuangan yang lebih tinggi dibandingkan mahasiswa yang masih junior. Shaari et al. (2013) menemukan bahwa tahun mahasiswa masuk ke Universitas memiliki hubungan positif dengan literasi keuangan. Hal ini menjelaskan bahwa mahasiswa yang masih junior memiliki literasi keuangan yang lebih rendah dibandingkan dengan siswa senior di perguruan tinggi. Berdasarkan penelitian-penelitian tersebut dapat dirumuskan hipotesis $H_{3}$ : Tahun masuk mahasiswa (angkatan) mempengaruhi literasi keuangan mahasiswa.

Cude et al. (2006) menjelaskan bahwa mahasiswa yang memiliki IPK yang tinggi akan memiliki keuangan yang lebih sehat atau lebih baik. Sabri et al. (2008) menjelaskan bahwa mahasiswa yang memiliki IPK yang tinggi memiliki permasalahan keuangan yang lebih sedikit dibandingkan mahasiswa yang memiliki IPK yang rendah. Krishna et al. (2010) menemukan bahwa mahasiswa yang memiliki IPK $<3$ memiliki tingkat literasi keuangan yang lebih tinggi dibandingkan mahasiswa yang memiliki IPK > 3 . Penelitiannya menyatakan bahwa tingkat literasi keuangan tidak ditentukan oleh kemampuan intelektual (yang dianalogikan dalam nilai IPK) tetapi lebih ditentukan oleh latar belakang pendidikan. Literasi keuangan mereka pelajari dari institusi pendidikan. Berdasarkan penelitian-penelitian tersebur dapat dirumuskan hipotesis yakni $H_{4}$ : IPK mempengaruhi literasi keuangan mahasiswa. 
Keown (2011) juga menemukan bahwa orang yang tinggal sendiri memiliki tingkat literasi keuangan personal yang lebih tinggi dibanding yang tinggal bersama pasangan ataupun orangtuanya. Hal ini disebabkan orang yang tinggal sendiri memiliki tanggung jawab untuk transaksi keuangan sehari-hari mereka dan keputusan keuangan lainnya. Berdasarkan penelitian-penelitian tersebut, maka hipotesisnya yakni $H_{5}$ : Tempat tinggal mahasiswa mempengaruhi literasi keuangan mahasiswa.

Lusardi, Mitchell, and Curto (2010) menemukan bahwa pendidikan dari orang tua merupakan prediktor yang besar dari literasi keuangan. Ansong and Gyensare (2012) menemukan bahwa terdapat hubungan positif antara pendidikan ibu dari responden dengan tingkat literasi keuangan responden. Berdasarkan penelitian-penelitian tersebut, maka dapat hipotesis yakni $H_{6}$ : Pendidikan orang tua mempengaruhi literasi keuangan mahasiswa.

Nidar dan Bestari (2012) menemukan bahwa pendapatan dari orang tua merupakan faktor yang signifikan terhadap tingkat literasi keuangan pada mahasiswa Jawa Barat. Keown (2011) menjelaskan terdapat hubungan antara pendapatan orang tua dengan pengetahuan keuangan. Hal ini menunjukan bahwa orang tua dengan pendapatan rumah tangga yang lebih tinggi cenderung memiliki tingkat literasi keuangan yang lebih tinggi karena mereka lebih sering menggunakan instrumen dan layanan finansial. Berdasarkan penelitian-penelitian tersebut, maka hipotesis yakni $H_{7}$ : Pendapatan orang tua mempengaruhi literasi keuangan mahasiswa.

\section{Metode Penelitian}

\section{Rancangan Penelitian}

Penelitian ini adalah penelitian deskriptif. Penelitian deskriptif adalah salah satu jenis penelitian yang tujuannya untuk menyajikan gambaran lengkap mengenai setting sosial atau hubungan antara fenomena yang diuji. Penelitian ini bertujuan untuk melihat gambaran tingkat literasi keuangan mahasiswa berdasarkan jenis kelamin, usia, program studi, angkatan, IPK, tempat tinggal, tingkat pendidikan orang tua dan tingkat pendapatan orang tua. Unit analisis dalam penelitian ini adalah mahasiswa Strata I Fakultas Ekonomi Universitas Trisakti. Data yang digunakan adalah cross sectional. Metode yang digunakan adalah penelitian survei yaitu metode penelitian kepada sekumpulan objek, tetapi hanya mengambil sebagian dari populasi tersebut dalam jangka waktu tertentu dengan menggunakan kuesioner.

\section{Variabel dan Pengukuran}

Variabel yang digunakan dalam penelitian ini terdiri dari sembilan variabel. Variabel tersebut adalah variabel dependen yakni variabel literasi keuangan mahasiswa. Variabel ini dapat didefinisikan sebagai kemampuan individu untuk membuat penilaian dan keputusan yang efektif mengenai penggunaan dan pengelolaan uang. Variabel ini diukur dengan ratarata persentase dari jawaban responden yang benar dari 30 pertanyaan pilihan ganda. Variabel ini diukur dengan pertanyaan-pertanyaan yang diadopsi dari Mandell (2008), Keown (2011) dan Madura (2011). Bagian ini, metode pengukuran yang digunakan adalah scoring atau penilaian berdasarkan banyaknya jumlah pertanyaan yang dijawab dengan benar oleh responden. Jumlah jawaban yang benar dihitung dan dibagi dengan seluruh pertanyaan kemudian dikali seratus persen. Jawaban responden kemudian dibagi kedalam tiga kategori (Nababan \& Sadalia, 2012). Chen and Volpe (1998) mengkategorikan literasi keuangan personal menjadi 3 kelompok, yaitu 1) < $60 \%$ yang berarti individu memiliki pengetahuan tentang keuangan yang rendah 2) 60\%-79\%, yang berarti individu memiliki pengetahuan tentang keuangan yang sedang 3) > 80\% yang menunjukan bahwa individu memiliki pengetahuan keuangan yang tinggi.

Variabel lainnya adalah variabel independen. Pertama adalah variabel jenis kelamin. Variabel jenis kelamin menjelaskan klasifikasi jenis kelamin dari responden laki-laki atau perempuan. Kedua, variabel usia. Variabel usia menjelaskan umur dari responden saat ini. Ketiga, variabel program studi. Variabel ini menjelaskan program studi yang diambil oleh responden. Variabel ini dibagi menjadi tiga kategori yakni 1) Manajemen 2) Akutansi dan 3) Ekonomi Pembangunan. Variabel keempat yakni variabel angkatan. Variabel ini menjelaskan tahun ketika responden masuk dan tercatat sebagai ma-hasiswa di perguruan tinggi. Variabel ini dibagi menjadi enam kategori: (1) 2008 (2) 2009 (3) 2010 (4) 2011 (5) 2012 dan (6) 2013. Kelima adalah variabel IPK. Variabel usia menjelaskan umur dari Indeks Prestasi Kumulatif dari responden saat ini. Variabel ini dibagi menjadi tiga kategori: 1) < 2,5 2) 2,5-3,00 3) > 3,00. Variabel keenam adalah variabel tempat tinggal. Variabel ini menjelaskan tempat ketika mahasiswa yang menjadi responden menetap selama masa perkuliahan. Variabel ini dibagi menjadi dua kategori: 1) tinggal sendiri atau kos dan 2) tinggal bersama orang tua. Variabel ketujuh adalah variabel tingkat pendidikan orang tua. Variabel usia menjelaskan jenjang pendidikan terakhir yang ditempuh oleh orangtua responden. Variabel ini dibagi menjadi enam kategori yakni 1) SD 2) SMP 3) SMA/Sederajat 4) Sarjana 5) Magister dan 6) Doktor. Variabel kedelapan adalah variabel tingkat pendapatan orang tua. Variabel usia menjelaskan tingkat penghasilan yang diperoleh orang tua responden selama sebulan baik dari penerimaan gaji, upah, ataupun penerimaan dari hasil usaha. Variabel ini dibagi menjadi tiga kategori yakni 1) < Rp. 5.000.000 2) Rp. 5.000.001-Rp. 10.000 .000 3) > Rp. 10.000 .000 . 


\section{Prosedur Pengumpulan Data}

Dalam penelitian ini, metode yang digunakan untuk mengambil sampel dengan menggunakan data primer. Fakultas Ekonomi Universitas Trisakti memiliki tiga program studi yaitu Ekonomi Pembangunan, Manajemen dan Akuntansi. Dalam penelitian ini, sebanyak 625 kuesioner disebarkan kepada mahasiswa strata I Fakultas Ekonomi Universitas Trisakti, tetapi 41 kuesioner tidak dapat digunakan, karena responden tidak mengisi kuesioner dengan lengkap. Jumlah kuesoiner yang dapat digunakan dalam penelitian ini adalah 584 kuesioner. Penyebaran kuesioner dilakukan pada bulan Pebruari hingga Maret 2014.

\section{Metode Analisis Data}

Data yang diperoleh dari hasil penelitian ini dianalisis dengan menggunakan analisis statistik deskriptif dan analisis ragam satu arah (ANOVA). Pertama adalah statistik deskriptif. Statistik deskriptif (Tabel 1) memberikan gambaran atau deskripsi suatu data yang dilihat dari nilai rata-rata (mean), median, modus, standar deviasi, maksimum dan minimum. Statistik deskriptif merupakan statistik yang menggambarkan atau mendeskripsikan data menjadi sebuah informasi yang lebih jelas dan mudah untuk dipahami. Kedua adalah analisis ragam satu arah (Oneway Analysis of Variancel Oneway ANOVA). Hal ini digunakan untuk membandingkan purata (mean) lebih dari dua sampel (Uyanto, 2009). Dalam pengujian hipotesis, kriteria umtuk menolak atau tidak menolak $H_{0}$ berdasarkan $P$-value jika sig. $<\alpha 0,05$, maka $H_{0}$ ditolak dan jika sig. $>\alpha 0,05$ maka $H_{0}$ diterima.

\section{Hasil Penelitian}

\section{Hasil Survei Tingkat Literasi Keuangan Secara Keseluruhan}

Tingkat literasi keuangan pada mahasiswa Strata I Fakultas Ekonomi Universitas Trisakti dapat dilihat pada Tabel 2. Cara penghitungan literasi keuangan adalah dengan cara jawaban responden yang benar lalu dibagi dengan seluruh pertanyaan. Nilai terendah adalah $16,67 \%$ dan tertinggi adalah $90,00 \%$. Hal ini menunjukkan bahwa dari 30 pertanyaan tentang literasi keuangan, ada responden yang hanya bisa menjawab lima pertanyaan dengan benar $(16,67 \%)$ dari 30 pertanyaan yang diajukan. Ada juga responden yang mampu menjawab 27 pertanyaan dengan benar $(90,00 \%)$ dari 30 pertanyaan yang diajukan. Menurut Chen and Volpe (1998) pengkategorian literasi keuangan personal menjadi tiga kelompok, yaitu 1) < $60 \%$ yang berarti individu memiliki pengetahuan tentang keuangan yang rendah 2) $60 \%-79 \%$, yang ber- arti individu memiliki pengetahuan tentang keuangan yang sedang, dan 3) > 80\% yang menunjukan bahwa individu memiliki pengetahuan keuangan yang tinggi. Berdasarkan pengkategorian tersebut, maka dalam Tabel 2 dapat dijelaskan secara keseluruhan tingkat rata-rata (mean) jawaban dari responden adalah $48,91 \%$ yang menunjukkan bahwa tingkat literasi keuangan pada mahasiswa Strata I Fakultas Ekonomi Universitas Trisakti berada pada tingkat yang rendah $(<60 \%)$. Nilai standar deviasi dari ratarata literasi keuangan bernilai $12,65765 \%$, dapat diketahui bahwa jawaban dari responden bervariasi.

Tabel 1

Statistik Deskriptif Berdasarkan Demografi

\begin{tabular}{|c|c|c|}
\hline Variabel & $\begin{array}{c}\text { Jumlah } \\
\text { Responden }\end{array}$ & Presentase \\
\hline \multicolumn{3}{|l|}{ Jenis Kelamin: } \\
\hline 1. Laki Laki & 207 & $35.4 \%$ \\
\hline 2. Perempuan & 377 & $64.6 \%$ \\
\hline \multicolumn{3}{|l|}{ Usia: } \\
\hline 1. < 19 Tahun & 59 & $10,1 \%$ \\
\hline 2. 19 Tahun -22 Tahun & 493 & $84,4 \%$ \\
\hline 3. > 22 Tahun & 32 & $5,5 \%$ \\
\hline \multicolumn{3}{|l|}{ Program Studi: } \\
\hline 1. Ekonomi Pembangunan & 37 & $6,3 \%$ \\
\hline 2. Manajemen & 151 & $25,9 \%$ \\
\hline 3. Akuntansi & 396 & $67,8 \%$ \\
\hline \multicolumn{3}{|l|}{ Angkatan: } \\
\hline 1. 2007 & 5 & $0,9 \%$ \\
\hline 2. 2008 & 4 & $0,7 \%$ \\
\hline 3. 2009 & 23 & $3,9 \%$ \\
\hline 4. 2010 & 104 & $17,8 \%$ \\
\hline 5. 2011 & 216 & $37,0 \%$ \\
\hline 6. 2012 & 232 & $39,7 \%$ \\
\hline \multicolumn{3}{|l|}{ IPK: } \\
\hline 1. $<2.5$ & 48 & $8,2 \%$ \\
\hline 2. $2,5-3,00$ & 162 & $27,7 \%$ \\
\hline 3. $>3,00$ & 374 & $64,0 \%$ \\
\hline \multicolumn{3}{|l|}{ Tempat Tinggal: } \\
\hline 1. Tinggal sendiri (kost) & 190 & $32,5 \%$ \\
\hline 2. Tinggal Bersama orang tua & 394 & $67,5 \%$ \\
\hline \multicolumn{3}{|l|}{ Tingkat Pendidikan Orang Tua: } \\
\hline 1. $\mathrm{SD}$ & 8 & $1,4 \%$ \\
\hline 2. SMP & 16 & $2,7 \%$ \\
\hline 3. SMA / Sederajat & 195 & $33,4 \%$ \\
\hline 4. Sarjana & 279 & $47,8 \%$ \\
\hline 5. Magister & 78 & $13,4 \%$ \\
\hline 6. Doktor & 8 & $1,4 \%$ \\
\hline \multicolumn{3}{|l|}{ Tingkat Pendapatan Orang Tua: } \\
\hline 1. $<$ Rp.5.000.000 & 134 & $22,9 \%$ \\
\hline 2. Rp.5.000.000 - Rp.10.000.000 & 268 & $45,9 \%$ \\
\hline 3. > Rp. 10.000 .000 & 182 & $31,2 \%$ \\
\hline
\end{tabular}

Tabel 2

Tingkat Literasi keuangan Secara Keseluruhan

\begin{tabular}{lc}
\hline \multicolumn{1}{c}{ Statistik Deskriptif } & Literasi Keuangan (\%) \\
\hline Minimum & 16,67 \\
Maximum & 90,00 \\
Mean & 48,91 \\
Standar Deviasi & 12,65765 \\
\hline
\end{tabular}


Tabel 3

Tingkat Literasi Keuangan Mahasiswa

\begin{tabular}{lrc}
\hline \multicolumn{1}{c}{ Katerori } & Jumlah & Persentase (\%) \\
\hline Rendah & 454 & 77.7 \\
Sedang & 125 & 21,4 \\
Tinggi & 5 & 0,9 \\
\hline Total & 584 & 100 \\
\hline
\end{tabular}

Tabel 4 menunjukkan persentase responden yang menjawab setiap butir pertanyaan dengan benar serta rata-rata jawaban yang benar untuk setiap area pertanyaan tentang literasi keuangan. Dalam area pengelolaan keuangan dapat diketahui rata-rata jawaban responden yang benar adalah $57,00 \%$. Area investasi dapat diketahui rata-rata jawaban responden yang benar adalah $38,62 \%$. Area hutang dapat diketahui rata-rata jawaban responden yang benar adalah $56,23 \%$. Area asuransi dapat diketahui rata-rata jawaban responden yang benar adalah 42,29\%.
Berdasarkan Tabel 4 dapat diketahui tingkat literasi keuangan mahasiswa Strata I Fakultas Ekonomi Universitas Trisakti yang paling rendah adalah pada area investasi yaitu sebesar 38,62\% dan tingkat literasi keuangan mahasiswa Strata I Fakultas Ekonomi Universitas Trisakti yang paling tinggi adalah pada area pengelolaan keuangan.

\section{Hasil Uji Hipotesis}

Berdasarkan interpretasi hasil penelitian yang telah dilakukan, maka pada bagian ini akan dibahas lebih lanjut. Penelitian ini dilakukan untuk mengetahui apakah jenis kelamin, usia, tahun masuk mahasiswa, IPK, tempat tinggal mahasiswa, pendidikan orang tua dan pendapatan orang tua memiliki pengaruh dengan literasi keuangan mahasiswa. Dalam penelitian ini terdapat tujuh hipotesis untuk diuji. Uraian-uraian dalam bagian ini dimaksudkan sebagai upaya untuk

Tabel 4

Persentase Responden yang Menjawab dengan Benar untuk Setiap Pertanyaan

\begin{tabular}{|c|c|c|c|}
\hline \multirow[b]{2}{*}{ Area dari Literasi Keuangan } & \multicolumn{3}{|c|}{ Tingkat Literasi Keuangan (\%) } \\
\hline & $\begin{array}{c}\text { Rendah } \\
<60 \%\end{array}$ & $\begin{array}{c}\text { Sedang } \\
60 \%-79 \%\end{array}$ & $\begin{array}{l}\text { Tinggi } \\
>80 \%\end{array}$ \\
\hline Pengelolaan Keuangan & 57,00 & & \\
\hline 1. Pengaruh inflasi untuk kelompok tertentu & 50 & & \\
\hline 2. Pajak penjualan & & 62,50 & \\
\hline 3. Perhitungan anggaran & & 69,52 & \\
\hline 4. Perhitungan present value & 42,50 & & \\
\hline 5. Pentingnya berinvestasi & 52,74 & & \\
\hline 6. Informasi tentang ATM & & 68,32 & \\
\hline 7. Pemahaman tentang investasi pendidikan & 34,25 & & \\
\hline 8. Pemahaman tentang pengeluaran & & 77,23 & \\
\hline 9. Pengertian laporan hutang & 54,62 & & \\
\hline 10. Pengertian anggaran & & 72,95 & \\
\hline 11. Nilai waktu dari uang & 42,47 & & \\
\hline Investasi & 38,62 & & \\
\hline 12. Tempat aman untuk menabung & & 74,49 & \\
\hline 13. Jenis investasi yang tepat ketika inflasi & 34,25 & & \\
\hline 14. Return terkecil dari investasi & 21,40 & & \\
\hline 15. Investasi yang memberikan return tinggi & 34,42 & & \\
\hline 16. Produk investasi & 22,27 & & \\
\hline 17. Bunga tabungan & 41,61 & & \\
\hline 18. Penjamin pasar modal & 16,10 & & \\
\hline 19. Kapan sebaiknya berinvestasi di saham & 46,06 & & \\
\hline 20. Masa jatuh tempo obligasi Indonesia & 56,51 & & \\
\hline Hutang & 56,23 & & \\
\hline 21. Cara tepat punya hutang & 55,31 & & \\
\hline 22. Perhitungan penggunaan hutang & 50,86 & & \\
\hline 23. Faktor-faktor yang dapat mengurangi pinjaman & 58,56 & & \\
\hline 25. Faktor-faktor yang mempengaruhi bunga pinjaman & 47,95 & & \\
\hline Asuransi & 42,29 & & \\
\hline 26. Manfaat asuransi kesehatan & 28,25 & & \\
\hline 27. Pentingnya asuransi jiwa & 31,16 & & \\
\hline 28. Kerugian leasing mobil & 22,09 & & \\
\hline 29. Premi asuransi & 54,11 & & \\
\hline 30. Asuransi mobil & & 75,86 & \\
\hline
\end{tabular}


mempertemukan antara hasil temuan dan analisis data dengan implikasi teori.

Ada dua macam hipotesis mengenai jenis kelamin. Pertama $H_{0}$ : Jenis kelamin tidak mempengaruhi literasi keuangan mahasiswa. Kedua $H_{l}$ : Jenis kelamin mempengaruhi literasi keuangan mahasiswa Hasil pengujian ditunjukan pada Tabel 5. Tabel tersebut menunjukkan bahwa jenis kelamin memiliki nilai sig. $0,040<\alpha 0,05$. Hal ini menunjukkan bahwa jenis kelamin mempengaruhi literasi keuangan mahasiswa, artinya mahasiswa perempuan memiliki tingkat literasi keuangan yang lebih tinggi dibandingkan mahasiswa laki-laki. Penelitian ini didukung oleh penelitian yang dilakuan oleh Bhushan and Medury (2013). Dalam penelitiannya menjelaskan bahwa terdapat perbedaan yang signifikan antara laki-laki dengan perempuan dalam literasi keuangan. Laki-laki memiliki literasi keuangan yang lebih tinggi dibandingkan perempuan. Selain itu, Krishna et al. (2010) menemukan bahwa mahasiswa perempuan memiliki literasi keuangan yang lebih tinggi dibandingkan mahasiswa laki-laki.

Hipotesis kedua yakni $H_{0}$ : Usia tidak mempengaruhi literasi keuangan dan $\mathrm{H}_{2}$ : Usia mempengaruhi literasi keuangan. Hasil pengujian ditunjukkan pada Tabel 5. Tabel tersebut menunjukkan bahwa usia memiliki nilai sig. $0,000<\alpha 0,05$. Hal ini menunjukkan bahwa usia mempengaruhi literasi keuangan mahasiswa. Hasil penelitian ini didukung oleh penelitian yang dilakukan oleh Shaari et al. (2013) menemukan bahwa usia mempengaruhi literasi keuangan mahasiswa. Hal ini menjelaskan bahwa mahasiswa yang berusia antara 18 tahun hingga 24 tahun termasuk dalam kelompok-kelompok berdasarkan demografi yang secara konsisten menunjukkan tingkat literasi keuangan yang rendah. Selain itu, Chen and Volpe (1998) yang menemukan tingkat literasi keuangan yang rendah pada peserta yang berusia 18-22 tahun. Alasan untuk rendahnya tingkat pengetahuan dapat dikaitkan dengan usia muda 18 sampai 22 tahun atau di bawah 30 tahun sebagai mayoritas dari mereka berada dalam tahap yang sangat awal siklus dari hidup finansial mereka. Dalam tahap siklus ini, mereka memiliki sejumlah masalah keuangan yang berkaitan dengan pengetahuan umum tentang keuangan, tabungan dan pinjaman, dan asuransi. Saat periode ini, sebagian besar pendapatan mereka dibelanjakan konsumsi daripada investasi.

Hipotesis ketiga adalah $H_{0}$ : Tahun masuk mahasiswa tidak mempengaruhi literasi keuangan dan $\mathrm{H}_{3}$ : Tahun masuk mahasiswa mempengaruhi literasi keuangan. Hasil pengujian ditunjukkan pada Tabel 5.
Tabel 5

ANOVA dan Literasi Keuangan

\begin{tabular}{lrcl}
\hline & $F$ Value & Significance & Keputusan \\
\hline Jenis Kelamin & 4,255 & 0,040 & $H_{1}$ diterima \\
Usia & 9,600 & 0,000 & $H_{2}$ diterima \\
Tahun Masuk & 0,308 & 0,908 & $\mathrm{H}_{3}$ ditolak \\
IPK & 21,452 & 0,000 & $\mathrm{H}_{4}$ diterima \\
Tempat Tinggal & 1,647 & 0,200 & $\mathrm{H}_{5}$ ditolak \\
Pendidikan orang tua & 1,873 & 0,097 & $\mathrm{H}_{6}$ ditolak \\
Pendapatan orang tua & 5,557 & 0,004 & $\mathrm{H}_{7}$ diterima \\
\hline
\end{tabular}

Tabel 5 tersebut menunjukkan bahwa usia memiliki nilai sig. 0,908 > $\alpha 0,05$. Hal ini menunjukkan bahwa tahun masuk mahasiswa tidak mempengaruhi literasi keuangan mahasiswa. Dalam penelitian ini, responden yang digunakan adalah mahasiswa yang masih aktif dari angkatan tahun 2007 sampai dengan tahun 2012. Hasil penelitian ini menunjukan bahwa tidak terdapat pengaruh antara tahun masuk dengan literasi keuangan. Hal ini dapat terjadi karena Fakultas Ekonomi Universitas Trisakti sampai saat ini belum memberikan pengetahuan tentang personal finance kepada mahasiswa, sehingga mahasiswa belum mengetahui bagaimana untuk mengelola keuangan pribadi dengan baik. Hasil penelitian ini didukung oleh penelitian yang dilakukan oleh Nidar dan Bestari (2012) yang menemukan bahwa tahun masuk mahasiswa tidak memiliki pengaruh dengan literasi keuangan mahasiswa. Selain itu, Krishna et al. (2010) dalam penelitiannya menjelaskan lama studi mahasiswa tidak memberikan pengaruh terhadap literasi keuangan.

Hipotesis keempat yakni $H_{0}$ : IPK mahasiswa tidak mempengaruhi literasi keuangan dan $H_{4}$ : IPK mahasiswa mempengaruhi literasi keuangan. Hasil pengujian ditunjukkan pada Tabel 5. Tabel tersebut menunjukkan bahwa usia memiliki nilai sig. $0,000<$ $\alpha 0,05$. Hal ini menunjukkan bahwa IPK mahasiswa mempengaruhi literasi keuangan mahasiswa. Penelitian ini menunjukkan bahwa semakin tinggi IPK, maka mahasiswa akan semakin baik dalam mengelola keuangan pribadinya. Penelitian ini didukung oleh penelitian yang dilakukan oleh Cude et al. (2006) yang menjelaskan bahwa semakin tinggi IPK maka mahasiswa tersebut memiliki keuangan yang lebih sehat atau lebih baik.

Hipotesis kelima yakni $H_{0}$ : Tempat tinggal mahasiswa tidak mempengaruhi literasi keuangan dan $H_{5}$ : Tempat tinggal mahasiswa mempengaruhi literasi keuangan. Hasil pengujian ditunjukkan pada Tabel 5. Tabel tersebut menunjukkan bahwa usia memiliki nilai sig. 0,200> $>0,05$. Hal ini menunjukkan bahwa tempat tinggal mahasiswa tidak mempengaruhi literasi keuangan mahasiswa. Penelitian ini menjelas- 
kan bahwa pada umumnya mahasiswa belum memiliki pendapatan dan masih bergantung terhadap orang tua, sehingga mereka belum dapat mengelola keuangan mereka dengan baik. Penelitian ini didukung oleh penelitian yang dilakukan oleh Nidar dan Bestari (2012) yang menemukan bahwa tempat tinggal tidak memiliki pengaruh terhadap literasi keuangan mahasiswa.

Hipotesis keenam yakni $H_{0}$ : Pendidikan orang tua tidak mempengaruhi literasi keuangan dan $H_{6}$ : Pendidikan orang tua mempengaruhi literasi keuangan. Hasil pengujian ditunjukkan pada Tabel 5. Tabel tersebut menunjukkan bahwa pendidikan orang tua memiliki nilai sig. $0,097>\alpha 0,05$. Hal ini menunjukkan bahwa pendidikan orang tua tidak mempengaruhi literasi keuangan mahasiswa. Penelitian ini didukung oleh penelitian yang dilakukan oleh Nidar dan Bestari (2012) yang menemukan bahwa pendidikan orang tua tidak memiliki pengaruh terhadap literasi keuangan mahasiswa.

Hipotesis ketujuh yakni $H_{0}$ : Pendapatan orang tua tidak mempengaruhi literasi keuangan dan $H_{7}$ : Pendapatan orang tua mempengaruhi literasi keuangan. Hasil pengujian ditunjukkan pada Tabel 5. Tabel tersebut menunjukkan bahwa pendapatan orang tua memiliki nilai sig. $0,004<\alpha 0,05$. Hal ini menunjukkan bahwa pendapatan orang tua mempengaruhi literasi keuangan mahasiswa. Penelitian ini didukung oleh penelitian yang dilakukan oleh Nidar dan Bestari (2012) yang menemukan bahwa pendapatan orang tua memiliki pengaruh yang signifikan terhadap literasi keuangan mahasiswa.

\section{Simpulan dan Implikasi}

Penelitian ini bertujuan untuk mengetahui bagaimana tingkat literasi keuangan mahasiswa Strata I Fakultas Ekonomi Universitas Trisakti. Penelitian ini juga bertujuan untuk mengetahui apakah terdapat hubungan antara jenis kelamin, usia, tahun masuk (angkatan), IPK, tempat tinggal mahasiswa, pendidikan orang tua dan pendapatan orang tua akan mempengaruhi literasi keuangan mahasiswa Strata I Fakultas Ekonomi Universitas Trisakti. Penelitian ini menggunakan sampel sebanyak 584 mahasiswa Strata I Fakultas Ekonomi Universitas Trisakti, yaitu mahasiswa Jurusan Ekonomi Pembangunan, Manajemen dan Akuntansi. Berdasarkan uraian pada analisis dan pembahasan sebelumnya, maka dapat disimpulkan bahwa tingkat literasi keuangan pada mahasiswa Strata I Fakultas Ekonomi Universitas Trisakti secara keseluruhan adalah $48,91 \%$, yang termasuk dalam kategori rendah $(<60 \%)$. Jenis kelamin, usia, IPK dan pendapatan orang tua memiliki pengaruh terhadap literasi keuangan mahasiswa. Tahun masuk mahasiswa (angkatan), tempat tinggal, dan pendidikan orang tua tidak memiliki pengaruh terhadap literasi keuangan.

Implikasi dari hasil penelitian ini ditunjukkan kepada universitas secara umum, khususnya Fakultas Ekonomi Universitas Trisakti. Mereka harus dapat memberikan pendidikan tentang personal finance kepada mahasiswanya. Hal ini agar mahasiswa sejak dini memiliki pengetahuan tentang keuangan pribadi agar mereka bisa menjadi mahasiswa yang cerdas, bisa mengatur keuangan dengan baik, dan bisa memiliki kehidupan yang sejahtera serta tidak mengalami kesulitan keuangan di masa depan.

\section{Daftar Referensi}

Ansong, A., \& Gyensare, M. A. (2012). Determinants of university working-students' financial literacy at the University of Cape Coast, Ghana. International Journal of Business and Management, 7 (9), 126-133.

ANZ Bank (2011). Adult financial literacy in Australia. Executive summary of the results from 2011 ANZ Survey.

Bhushan, P., \& Medury, Y. (2013). Financial literacy and its determinants. International Journal of Engineering, Business and Enterprise Applications (IJEBEA), 4(2), 155-160.

Chen, H., \& Volpe, R. P. (1998). An analysis of financial literacy among college students. Financial Services Review, 7(1), 107-128.

Cude, B. J., Lawrence F. C., Lyons A. C., Metzger, K., LeJeune, E., Marks, L., \& Machtmes, K. (2006), College students and financial literacy: What they know and what we need to learn. Eastern Family Economics and Resource Management Association 2006 Conference.

Ibrahim, M. L., \& Alqaydi, F. R. (2013). Financial literacy, personal financial attitude, and forms of personal debt among residents of the UAE. International Journal of Economic and Finance, 5 (7), 126-138.

Keown, L. A. (2011). The financial knowledge of Canadians. Component of Statistics Canada Catalogue, 11-008-X, 30-39.

Krishna, A., Rofaida, R., \& Sari, M. (2010). Analisis tingkat literasi keuangan di kalangan mahasiswa dan faktor-faktor yang mempengaruhinya. Proceedings of the $4^{\text {th }}$ International Conference on Teacher Education; Join Conference UPI \& UPSI Bandung, Indonesia.

Lusardi, A., Mitchell, O. S., \& Curto, V. (2010). Financial literacy among the young: Evidence and implications for consumer policy. NBER Working Paper, 15352. 
Madura, J. (2011). Personal finance. Fourth Edition. United State of America: Pearson Education, Inc.

Mandell, L. (2008). The financial literacy of young American adult: Results of the 2008 national jump\$tart coalition survey of high school seniors and college students. Diunduh 1 Agustus 2014, dari http://www.jumpstart.org/assets/files/2008SurveyBook. pdf.

Nababan, D., \& Sadalia, I. (2012). Analisis personal financial literacy dan financial behavior mahasiswa strata I fakultas ekonomi Universitas Sumatera Utara. Diunduh 1 Agustus 2014, dari http://repository.usu.ac.id/handle/123456789/34 557.

Nidar, S. R., \& Bestari, S. (2012). Personal literacy among university students (case study at Padjajaran University students, Bandung, Indonesia. World Journal of Social Sciences, 2(4), 162-171.

Remund, D. L. (2010). Financial literacy explicated: The case for a clear definition in an increasingly complex economy. The Journal of Consumer Affairs, 44(2), 276-295.

Sabri, M. F., Othman, M. A., Masud, J., Paim, L., MacDonald, M., \& Hira, T. K. (2008). Financial behavior and problems among college students in Malaysia: Research and education implication. Consumer Interest Annual, 54, 166-170.

Servon, L., \& Kaestner, R. (2008). Consumer financial literacy and the impact of online banking on the financial behavior of lower-income bank customers. Journal of Consumers Affairs, 42(2), 271-305.
Shaari, N. A., Hasan, N. A., Mohamed, R. K. M. H., \& Sabri, M. A. J. M. (2013). Financial literacy: A study among the university student. Interdisciplinary Journal of Contemporary Research in Business, 5(2), 279-299.

Taft, M. K., Hosein, Z. Z., \& Mehrizi, S. M.T. (2013). The relation between financial literacy, financial wellbeing and financial concerns. International Journal of Business and Management, 8(11), 63-75.

Uyanto, S. S. (2009). Pedoman analisis data dengan SPSS. Edisi Ketiga. Yogyakarta: Graha Ilmu.

Visa (2012). Visa International Financial Literacy 2012. Diunduh 1 Agustus 2014, dari https:// www.practicalmoneyskills.com/summit2012/de cks/bodnar.pdf.

Vitt, L. A., Andersen, C., Kent, J., Lyter, D. M., Siegenthaler, J. K., \& Ward, J. (2000). Personal finance and the rush to competence: Financial literacy education in the U.S. Virginia: Institute for Socio-Financial Studies.

Widayati, I. (2012). Faktor-faktor yang mempengaruhi literasi finansial mahasiswa fakultas ekonomi dan bisnis Universitas Brawijaya. Jurnal Akutansi dan Pendidikan 1(1), 89-99.

Worldbank (2011). The Global Financial Inclusion (Global Findex) Database. Diunduh 1 Agustus 2014, dari http://econ.worldbank.org/WBSITE/ EXTERNAL/EXTDEC/EXTRESEARCH/EXT PROGRAMS/EXTFINRES/EXTGLOBALFI N/0,,contentMDK:23147627 pagePK:6416817 6 piPK:64168140 theSitePK:8519639,00.html. 